\title{
COVID-19 \& Quarantine Measures: A Comparison between India \& Russia
}

\author{
Michail A. Osadchuk, ${ }^{\dagger}$ Maxim V. Trushin, ${ }^{*}$ and Alexey M. Osadchuk ${ }^{\top}$
}

\section{Abstract}

The Governments of the different countries are taking a wide range of measures in response to the COVID-19 outbreak. For assessing the rigour of quarantine measures, the Blavatnik School of Government at the University of Oxford has launched the world's first COVID-19 government response tracker - the Oxford Coronavirus Government Response Tracker (OxCGRT). This tool aims to track and compare policy responses of governments around the world rigorously and consistently. According to the COVID-19 Government Response Stringency Index (GRSI), the strictest measures are in India (97.37 points), and less stringent ones are in the Russian Federation (63.89 points). The study compares restrictive measures in India and Russia, analyses their impact on the spread of COVID-19; and estimates mortality rates. Besides, the study also probes population coverage aimed at diagnosing through the use of testing methods and possible economic consequences of quarantine measures.

Keywords: Quarantine in India; Quarantine in Russia; COVID-19 Pandemic Growth; Population Coverage by Testing for COVID-19

\footnotetext{
+ The Federal State Autonomous Education Institution of Higher Training The First Sechenov Moscow State Medical University under the Ministry of Health of the Russian Federation (Sechenovskiy University) , 2, bld.4, of 106, Bolshaya Pirogovskaya Street, Moscow 119435, Russian Federation

${ }^{¥}$ Kazan Federal University, Kremlyovskaya 18, 420008 Kazan, Russia

${ }^{*}$ Corresponding Author, Email: mtrushin@mail.ru

'Samara State Medical University under the Ministry of Health of the Russian Federation, 89 Chapayevskaya Street, Samara 443099, Russian Federation.

(C) 2020 Osadchuk et al. This is an Open Access article distributed under the terms of the Creative Commons Attribution License (http://creativecommons.org/licenses/by/2.0), which permits unrestricted use, distribution, and reproduction in any medium, provided the original work is properly cited.
} 


\section{Introduction}

The first mention of SARS coronavirus dates back to 2002, when an outbreak of severe acute respiratory syndrome characterised by severe pneumonia and respiratory failure was recorded. Viruses of this type have been detected in bats. On 12 December 2019, an outbreak of pneumonia caused by the SARS coronavirus, subsequently named COVID-19, began in Wuhan, the capital city of the Hubei Province, People's Republic of China. It is believed that people were infected with this virus in the seafood market (Zhou et al., 2020). It should be noted that China informed WHO about the emergence of a new type of pneumonia only on 31 December 2019. On 11 February 2020 WHO named a new coronavirus disease - COVID-19. In a relatively short time, COVID-19 left the borders of China and spread to various countries. As a result, on 11 March 2020 WHO announced that the outbreak of COVID-19 had taken the shape of a pandemic (Chappell, 2020). ${ }^{1}$

The pandemic of the new COVID-19 infection has been accompanied by a number of restrictive measures taken by governments in various countries. However, the stringency measures vary from country to country. Several universities (Imperial College London; The Blavatnik School of Government, \& University of Oxford; John Hopkins University) and organisations, including the World Health Organization (WHO), have developed various methods/models to keep track of COVID-19 including the method to assess the rigour of quarantine. The Blavatnik School of Government at the University of Oxford developed the COVID-19 Government Response Stringency Index (GRSI). For its calculation of the latest version, it presents data collected from public sources on nine indicators: eight of them are policy-related, ranked on an ordinal scale (school closure; workplace closure; cancellation of public events; cancellation of gatherings; public transport closures; stay-at-home restrictions, restriction on internal movement; international travel control), and one is financialsupport for population incomes. The maximum index value is 100 , and the minimum is 0 points (Blavatnik School of Government, \& University of Oxford, 2020). This allows the parties concerned to examine differences in government responses and compare them with the number of COVID19 cases. It is important to note that the index does not aim to measure countries' appropriateness or effectiveness, but instead offers them an opportunity to compare responses to quarantine measures and learn from each other (Blavatnik School of Government, \& University of Oxford, 2020).

Globally, it has been noted that the government responses are becoming more stringent as the epidemic severity grows (Blavatnik School of Government \& University of Oxford, 2020). The COVID-19 GRSI was calculated for different countries according to its old version, where the parameter "stay-at-home restriction" was not taken into account. According to OXCGRT estimates the most stringent restrictive measures were taken in India (the COVID-19 GRSI 97.35 points), less stringent measures were implemented in Italy (93.25 points), Spain (89.41 points), France (89.41 points) and Russia (63.89 points). ${ }^{2}$ Studying the effect of various severity of infection spread; restrictive measures on economic and social life will allow us to find the optimal balance between them in the event of epidemics and pandemics in the future.

The review aims to compare isolation measures between India and Russia as both countries continue to maintain strong relations. It aims to analyse the results achieved to contain the COVID-19 epidemic. The findings reveal that measures of India as the most stringent, while the measures are least stringent in Russia.

\footnotetext{
${ }^{1}$ Rolling updates on coronavirus disease (COVID-19). World Health Organization. Retrieved on 18 June 2020 from, https://www.who.int/emergencies/diseases/novel-coronavirus-2019/events-as-they-happen

${ }^{2}$ Coronavirus Strigency Index: A look at Government responses to Covid-19 (2020, 30 March). Financial Times. Retrieved on 31 March 2020 from, https://www.bsg.ox.ac.uk/node/5421
} 
The review begins with a discussion of the features of anti-epidemic measures in India. This is followed by a discussion of quarantine measures of the country. Then it goes on to critically discuss the restrictive measures and Covid-19 infection control results in Russia. The results and prospects are discussed in the final section.

\section{Features of Anti-Epidemic Measures in India}

The first COVID-19 case in India was reported on 30 January 2020. Then, on 2 and 3 February 2020 two more COVID-19 cases were detected. All three patients reported having travelled to Wuhan, China. After this, the infections were not recorded for a month, until 2 March 2020 when two new COVID-19 cases were reported. After this date, there was a significant increase in the number of positive patients. Until 25 March 2020 quarantine measures were only aimed at preventive work with the population. There were developed guidelines for personal hygiene, surveillance, contact tracing, quarantine, diagnostics, laboratory tests, and infection management. All who arrived in the country were asked to comply with the 14-day quarantine. People were advised not to visit public places and markets selling live animals. Medical centres were encouraged to provide only emergency services. Doctors received recommendations to use the telemedicine system to provide advice, including issues related to COVID-19 prevention and spread. By 25 March 2020 various public facilities, such as hotels, educational institutions, colleges, railway cars, were redesigned for temporary accommodation of quarantined people. Stadiums also began to be used as insulators for patients. Some Indian states redeployed hospitals to exclusively treat COVID-19 patients. On 21 March 2020, the country's Prime Minister, Mr Narendra Damodar Modi addressed the nation, announcing a 14-hour voluntary public curfew. And on 25 March 2020, strict quarantine measures were introduced in connection with the spread of the disease. During the quarantine period on 25 March 2020562 COVID-19 infections were registered in India. 12 people died from it ; the daily increase in infection active cases was 48 people (Diwanji, 2020a). At first, the period of restrictive measures was three weeks: from 25 March to 14 April 2020. On 14 April 2020 when 10541 cases of COVID-19 were recorded in India, quarantine of similar severity was extended for another 19 days until 3 May 2020. In accordance with the measures taken, a "stay-at-home restriction" was imposed. Automobile, air and rail transport services were suspended, with the exception of vital goods transportation, fire, police and emergency services. Full-time activities of educational institutions, the work of industrial enterprises and hotel complexes were prohibited. Grocery stores, banks and ATMs, petrol stations, shops, e-commerce dealing with essential goods, and their production were exempt from taxes. The Ministry of Home Affairs (MHA) stated that anyone who did not comply with the restrictions might end up in prison for up to a year (Tripathi, 2020). Arrests were made in all states for violating quarantine standards, such as leaving home without a good reason, opening businesses, and violating quarantine requirements for building maintenance. To ensure a continuous supply of essential goods throughout the country during the entire quarantine period, it was recommended to use electronic resources (India Today, 2020). At the same time, several Indian states even banned food delivery services, despite the absence of a ban from the republican government (Verdict Foodservice, 2020).

Nevertheless, since 20 April 2020 the lockdown was slightly eased when the Government of India allowed opening an agricultural business, including a business related to the production and sale of dairy products, seafood/aquaculture, as well as shops selling agricultural goods. Some community work was allowed to be resumed following social distancing principles. Freight vehicles (vehicles, trains, planes) were allowed to travel around the country. Banks and government centres participating in preferential allocation of resources were also opened (BBC News, 2020a). From 25 April 2020 it was allowed to open small retail stores with $50 \%$ of employees, subject to mandatory observance of social distancing standards (Aleem, 2020). On 29 
April 2020 the MHA developed guidelines for movement of people between states and also of those in distress. However, such residents still had to undergo appropriate checks, quarantine and surveillance (Jagannath, 2020).

On the last day of the most stringent quarantine measures, that is on 3 May, a total of 39980 confirmed COVID-19 cases were recorded in India, the number of active cases was 27838 , the daily increase in active cases was 1732 , the total number of deaths was 1323 , amounting to 100 deaths per day. Moreover, the doubling time of the epidemic reached 12 days (Diwanji, 2020a). Before this, on 1 May the Indian government had divided the country into green, red and orange zones, where it was planned to conduct quarantine measures of various stringency (The Economics Times, 2020b). Territory division into zones was based on COVID-19 occurrence frequency. In the green zone, there should have been no cases of infection in the last 21 days. A high infection incidence and doubling characterised the red zone. The orange zone was represented by regions with few COVID-19 infections. So, from 4 May 2020 intercity buses with no more than $50 \%$ occupancy were allowed in green areas. In all the three zones, private offices with up to $33 \%$ of employees were allowed. It was possible to move on a twowheeled vehicle without a passenger, on fourwheeled vehicles with a driver and two passengers. In red zones, the use of any public transport was still prohibited. In orange regions, only private transport in the form of a taxi with a driver and with no more than 2 passengers was allowed. A complete ban on movement from 7 $\mathrm{pm}$ to $7 \mathrm{am}$ was introduced for all the three zones except for persons whose work was connected with strategic life support. Also, from 4 May 2020 rail transport, the metro, full-time activities of educational organizations, entertainment facilities, social events, temple visiting, intercity buses with more than 50\% coverage, a taxi with a driver and more than two passengers (Table 1) (Banerjea, 2020) remain banned. Such restrictions persisted until 31 May 2020 (BBC News, 2020b), which is explained by the preservation of a sufficiently high rate of
COVID-19 distribution for the transition to the restriction lifting next stage.

\section{Results of Quarantine Measures in India}

The pandemic growth rate in India slowed down from doubling every 3-4 days (Senapati et al., 2020) before restrictive measures were introduced to doubling every six days by 6 April 2020 (Ramesh \& Basu, 2020). By 19 April, infection cases doubling was recorded once every ten days (Basu, 2020). By 4 May 2020 its rate slowed even further to doubling every twelve days (Soni, 2020). Further, by 17 May, the epidemic doubling rate slowed down to 13.6 days (Table 2) (The Times of India, 2020). By the end of the third stage of quarantine measures, that is on 17 May 2020, the total number of COVID-19 cases reached 90 927, and the death toll increased to 2872 . The number of active cases was up to 53831 (Business Standard, 2020). The total number of deaths from COVID19 by 17 May 2020 was 83 people (Ritchie et al., 2020). Despite the most stringent restrictive measures, the epidemic continues to grow in India, but its pace is steadily declining (Diwanji, 2020) (Table 2).

Up to 17 May 2020, India daily performed 0.07 COVID-19 tests per 1000 of the population. Throughout the epidemic, the testing frequency was 1.61 persons per 1000 , which is significantly less than in the leading countries and Russia, where at that time 47.39 COVID-19 tests were run per 1000 people, and now 1.61 tests are done daily per 1000 (Hasell et al., 2020) (Table 2). Currently, India has 23 times fewer tests than Russia. It should be assumed that insufficient diagnosis of COVID-19 mild cases and carriage due to the dominating performance of tests in patients with moderate to severe infection leads to higher mortality of COVID-19 patients in the Indian population compared to the Russian one. Thus, most countries in the pandemic's early stages did not aim to diagnose COVID-19 in individuals with mild symptoms (Sevillano et al., 2020). Analysis of the outbreak's early phase before 23 January showed that $86 \%$ of COVID19 infections were not diagnosed, and these unregistered cases were the source of infection in $79 \%$ of people (Li et al., 2020). However, 
official data provided by the Indian side do not Economics Times, 2020a). Nevertheless, confirm this point of view. On the contrary, they mortality from COVID-19 in India is more than indicate that $75-80 \%$ of the detected COVID-19 three times higher than in Russia: $3.1 \%$ and $0.9 \%$, cases in India were asymptomatic or mild, which respectively, which requires additional analysis was detected by testing (Dixit, 2020; The (Table 2) (Ritchie et al., 2020).

\begin{tabular}{|c|c|c|}
\hline Activities & Russia & India \\
\hline COVID-19 GRSI in points & 63.9 & 97.4 \\
\hline $\begin{array}{l}\text { Maximum quarantine } \\
\text { introduction }\end{array}$ & Not introduced & Introduced \\
\hline Rail and metro & Allowed & Forbidden \\
\hline Educational institutions & $\begin{array}{l}\text { Full-time education } \\
\text { prohibited }\end{array}$ & $\begin{array}{l}\text { Full-time education } \\
\text { prohibited }\end{array}$ \\
\hline $\begin{array}{l}\text { Cinemas, theatres, shopping and } \\
\text { entertainment centres, cafes, } \\
\text { restaurants and other leisure } \\
\text { places }\end{array}$ & Activity paused & Activity paused \\
\hline Places of religious services & Partially closed to visitors & Activity paused \\
\hline $\begin{array}{l}\text { Prohibition of any movement } \\
\text { except for safety reasons from } 7 \\
\text { pm to } 7 \text { am }\end{array}$ & Not introduced & Ban introduced \\
\hline Taxi & Allowed & Forbidden \\
\hline Intercity buses & Allowed & Forbidden \\
\hline Air transportation of passengers & Paused & Paused \\
\hline Leaving home & $\begin{array}{l}\text { Allowed for walking } \\
\text { animals, shopping for } \\
\text { essential goods, visiting } \\
\text { pharmacies and taking out } \\
\text { garbage }\end{array}$ & Allowed only in emergency \\
\hline $\begin{array}{l}\text { Essential goods stores/e - } \\
\text { commerce }\end{array}$ & Allowed & Allowed \\
\hline $\begin{array}{l}\text { Interstate and domestic } \\
\text { movement of goods }\end{array}$ & Allowed & Allowed \\
\hline $\begin{array}{l}\text { Possible sanctions for unregulated } \\
\text { leaving home }\end{array}$ & Fine & $\begin{array}{l}\text { Arrest } \\
\text { A year of imprisonment }\end{array}$ \\
\hline
\end{tabular}

\section{Restrictive Measures in Russia}

During the COVID-19 spread in Russia, restrictive measures were not as stringent as in India (Table $1)$, and they were introduced gradually. From 16 March 2020 the Ministry of Science recommended that universities transfer to distance learning (Order of the Ministry of Science and Higher Education of the Russian Federation (dated 14.03.2020) No. 397, 2020). From 17 March 2020 schools of the Russian
Federation were transferred to distance learning (Order of the Ministry of Education of the Russian Federation (dated 17.03.2020) No. 104, 2020). On 27 March 2020 a total of 1036 COVID19 cases were registered in Russia in 58 regions with four fatal cases. Following Presidential Decree No. 206 of 25 March 2020 non-working days were established from 30 March 2020 except for organizations responsible for citizens and the state's livelihoods. These included continuously operating organisations: medical 
facilities and pharmacies; organisations providing food and essential goods, and performing urgent work; institutions providing emergency financial services; other organisations operating under decisions of the supreme executive authority of the Russian Federation constituent entity, based on the sanitary-epidemiological situation and the COVID-19 spread. Activities not regulated by presidential decree were discontinued or transferred to a remote form. Unlike India, Russia maintained public transport operation. People were allowed to go out to walk animals, take out the garbage and buy essential goods. No curfew was imposed. Rail transport continued to operate, and citizens had the right to internal movement. $1.5 \mathrm{~m}$ social distance was introduced, excluding taxi rides. A similar regime was prolonged twice: from 5 April to 30 April 2020 (Decree of the President of the Russian Federation (dated 02.04.2020) N 239, 2020) and from 1 May to 11 May 2020 (Decree of the President of the Russian Federation (dated 28.04.2020) N 294, 2020). It should be noted that in Russia, the period of the most stringent restrictive measures was prolonged by 43 days, in India, by 40 days (Table 1). At the end of this period, a transition to gradual lifting of restrictive measures began in some regions.

\section{Results of Covid-19 Infection Control in Russia}

By 30 March 2020, the first day of restrictive measures, the total number of COVID-19 patients was 1 836, of which 1761 were active cases, nine patients had died, two recovered. The estimated infection doubling rate was four days. By 19 April 2020, in the middle of the most stringent restriction period in Russia there were 42853 cases of the infection, of which 39201 were active, 3291 patients recovered, 361 people had died. During the day from 18 to 19 April 2020 the number of active infections increased by 5 778. 234 people recovered, and 48 people died. Despite the epidemic growth, its pace was significantly reduced until the infection doubling in 6.6-6.7 days, which testified to the effectiveness of the measures taken (Statista Research Department (SRD), 2020).

It should be noted that the epidemic in Russia also continues to grow at present, however, as well as in India, its pace is regressive. So, already on 11 May 2020 (the last day of the most stringent restrictions) infection doubling was observed in 16-17 days, and by May 17 there was a decrease in 21-23 days (Table 2). Statistics on 22 May 2020 show a slowdown in the pandemic growth to less than 3\% per day. ${ }^{3}$ In Russia, the highest rates of population testing for COVID-19 on 17 May 2020 were 47.39 tests per thousand of the population. This figure continues to grow, and now it has already exceeded 50 per thousand, which largely explains such significant numbers of detected COVID-19 cases, which crossed the 300000 thresholds. Such a wide population coverage makes it possible to detect mild and asymptomatic cases of the disease, take additional restrictive measures against identified individuals, start timely treatment and, thereby, reduce the likelihood of an epidemic spread and mortality from COVID-19, which is currently one of the lowest in the world.

Despite the absolute increase in mortality from COVID-19 in Russia, the relative mortality rate does not exceed $0.9 \%$, while in India it is $3.1 \%$, and on average in the world, it reaches $6.3-6.5 \%$ (Lazzerini \& Putoto, 2020). It should be noted that by 22 May 2020 both in India and Russia there was a proportional increase in the number of deaths from coronavirus infection by two times, which is associated with a general increase in the number of active cases of the disease and, accordingly, its severe cases. (Ritchie et al., 2020). Very optimistic is the fact that the infected mortality rate (IFR) with a 95\% probability indicates that, taking into account undiagnosed cases, the mortality rate from COVID-19 infection in the world is $0.94 \%$ (WHO, 2020). It is believed that $35 \%$ of people with COVID-19 have no symptoms at all; mortality in people with clinical manifestations ranges from $0.2 \%$ to $1 \%$ (Azad, 2020).

\footnotetext{
${ }^{33}$ Daily COVID-19 case growth in Russia stays under 10,000 for seven days in a row (22 May
}

2020).TASS:Russian News Agency. Retrieved on 22 May 2020 from, https://tass.com/society/1159177 


\begin{tabular}{|c|c|c|c|c|c|c|}
\hline Indicator & $\begin{array}{l}\text { COVID-19 } \\
\text { statistics in } \\
\text { Russia on the } \\
\text { first day of } \\
\text { quarantine } \\
\text { measures (30 } \\
\text { March 20) }\end{array}$ & $\begin{array}{l}\text { COVID-19 } \\
\text { statistics in } \\
\text { India on the } \\
\text { first day of } \\
\text { quarantine } \\
\text { (25March20) }\end{array}$ & $\begin{array}{l}\text { Russia on } \\
11 \text { May } \\
2020\end{array}$ & $\begin{array}{l}\text { India on } 3 \\
\text { May } 2020\end{array}$ & $\begin{array}{l}\text { Russia on } \\
17 \text { May } \\
2020\end{array}$ & $\begin{array}{l}\text { India on } 17 \\
\text { May } 2020\end{array}$ \\
\hline $\begin{array}{l}\text { Doubling of } \\
\text { infection cases/ } \\
\text { days }\end{array}$ & $\approx 4$ & $3.3-4.3$ & 16 & 12 & 21-23 & 13.6 \\
\hline $\begin{array}{l}\text { Total number of } \\
\text { cases }\end{array}$ & 1836 & 562 & 221344 & 39980 & 281752 & 90927 \\
\hline $\begin{array}{l}\text { Number of active } \\
\text { cases (total) }\end{array}$ & 1761 & 519 & 179539 & 27838 & 211748 & 53831 \\
\hline Deaths (total) & 9 & 12 & 2009 & 1323 & 2631 & 2872 \\
\hline $\begin{array}{l}\text { Number of the } \\
\text { recoveries per } \\
\text { day }\end{array}$ & 2 & 3 & 5495 & 812 & 4207 & 3926 \\
\hline Total recovered & 66 & 43 & 39801 & 10819 & 67373 & 34224 \\
\hline $\begin{array}{l}\text { Daily increase in } \\
\text { active cases per } \\
\text { day }\end{array}$ & 299 & 48 & 6067 & 1732 & 9333 & 5408 \\
\hline $\begin{array}{l}\text { Number of } \\
\text { deaths per day }\end{array}$ & 1 & 2 & 94 & 100 & 94 & 83 \\
\hline $\begin{array}{l}\text { Number of cases } \\
\text { per million of the } \\
\text { population }\end{array}$ & - & - & $\approx 1200$ & $\begin{array}{l}\approx 29 / \\
\text { million }\end{array}$ & $\begin{array}{l}\approx 2000 / \\
\text { million }\end{array}$ & $\begin{array}{l}\approx 65 / \\
\text { million }\end{array}$ \\
\hline $\begin{array}{l}\text { Number of tests } \\
\text { per day per } \\
\text { thousand of the } \\
\text { population }\end{array}$ & $<0.3$ & $<0.1$ & 1.4 & $<0.1$ & $<1.7$ & $<0.1$ \\
\hline $\begin{array}{l}\text { Total number of } \\
\text { tests per } \\
\text { thousand of the } \\
\text { population }\end{array}$ & 2.4 & $<0.01$ & 38.6 & 0.8 & 47.4 & 1.6 \\
\hline $\begin{array}{l}\text { Mortality,\% } \\
\text { (ratio of } \\
\text { mortality to the } \\
\text { diagnosed case) }\end{array}$ & - & 2.1 & 0.9 & 3.3 & 0.9 & 3.1 \\
\hline $\begin{array}{l}\text { Mortality per } \\
\text { million of the } \\
\text { population }\end{array}$ & - & - & 13.7 & $<1$ & 17.4 & 2.1 \\
\hline
\end{tabular}

\section{Mortality linked to COVID-19}

According to the WHO situational report, as of 13 April 2020, the overall mortality rate from COVID-19 was $6.3 \%$ (WHO, 2020). The difference in mortality between countries is primarily due to the age structure of the sick. For example, high mortality rates are associated mainly with the older age of the deceased. So, in Italy, it was 80.5 years, with an average age of patients of 62 years (Ministry of Health, 2020). A similar trend exists in India, where the mortality rate of people over 60 was about $9 \%$, with an average mortality rate of 2.7-3.1\% (Narayan \& Nagarajan, 2020). Moreover, the primary cohort of infected people in India was represented by persons aged 21-40 years, who had the lowest mortality rates (Diwanji, 2020b). A similar situation exists in Russia, where more than $43-46 \%$ of the infected are people aged $18-45$, who have a relatively low 
mortality rate. Moreover, people over 65 make up only about $15 \%$ of cases (SRD, 2020b). For comparison, in Italy, where the mortality rate from COVID-19 exceeds $14 \%$, about $40 \%$ of patients were over 70 years old (SRD, 2020a).

WHO reports that more than $95 \%$ of deaths from COVID-19 in Europe occur among people over 60 years of age, and of these, there are more than $50 \%$ of deaths among people over 80 . Moreover, $80 \%$ of the dead had at least one concomitant pathology (cardiovascular diseases, arterial hypertension, diabetes mellitus) (Kluge, 2020). The Korean example shows that although the overall mortality rate from COVID-19 is $0.9 \%$, mortality among people aged 80 and over reaches 9.3\% (Kang, 2020). Researchers from other countries provide similar data. For example, according to them, mortality rates among people over 80 range from 7.8 to $30 \%$, while in patients younger than 40 years, mortality rates usually do not exceed $0.3-0.4 \%$ (Mahase, 2020; Wisconsin Department of Health Services, 2020).

Currently, we can observe an increase in the number of coronavirus deaths. On 15 June 2020, the total number of deaths worldwide exceeded 430 thousand. The largest number of deaths is registered in the United States, but the highest mortality per million people is found in Belgium. Russia is in 36th place, and India is in 83rd place in the list of deaths number per million people (Table 3). ${ }^{4}$

\begin{tabular}{|c|c|c|c|}
\hline Countries & COVID-19 deaths & Population & Mortality per million \\
\hline Belgium & 9655 & 11.4 & 845.3 \\
\hline Spain & 27136 & 46.7 & 580.8 \\
\hline Italy & 34345 & 60.4 & 568.3 \\
\hline Sweden & 4874 & 10.2 & 478.3 \\
\hline France & 29360 & 67 & 438.7 \\
\hline US & 115572 & 327.2 & 353.3 \\
\hline Canada & 8218 & 37 & 221.8 \\
\hline Great Britain & 41698 & 66.5 & 627.1 \\
\hline Russia & 6938 & 144.5 & 48.02 \\
\hline India & 9520 & 1352.6 & 7 \\
\hline \multicolumn{4}{|c|}{$\begin{array}{l}\text { Source: Coronavirus (COVID-19) deaths worldwide per one million population as of June 15, } \\
\text { 2020, by country.Statisticia. Retrieved on } 15 \text { June } 2020 \text { from, } \\
\text { https://www.statista.com/statistics/1104709/coronavirus-deaths-worldwide-per-million- } \\
\text { inhabitants/ }\end{array}$} \\
\hline
\end{tabular}

COVID-19 infection analysis yielded data among inpatients (Emami et al., 2020). So, indicating that arterial hypertension, cardiovascular diseases can increase mortality cardiovascular disease, diabetes mellitus, from COVID-19 by $10.5 \%$, diabetes by $7.3 \%$, smoking, chronic obstructive pulmonary disease, chronic respiratory disease by $6.3 \%$, arterial malignant tumour and chronic kidney disease hypertension by $6.0 \%$ and malignant neoplasm were the most frequently diagnosed pathologies by $5,6 \%$ (Wu \& McGoogan, 2020). The risk of

\footnotetext{
${ }^{4}$ Coronavirus (COVID-19) deaths worldwide per one million population as of June 15,2020 , by country. Statisticia. Retrieved on 15 June 2020 from,
}

https://www.statista.com/statistics/1104709/coronaviru s-deaths-worldwide-per-million-inhabitants/ 
severe COVID-19 cases and mortality was almost 2.5 times higher in patients with hypertension, especially among the elderly (Bulut \& Kato, 2020). Mortality rates may also be affected by the features of counting such cases in different countries. For example, in the UK, Germany, Italy and several other countries any dead person infected with COVID-19 is considered dead from coronavirus infection in the presence of any concomitant pathology (Henriques, 2020). In Russia and India, there is another counting practice, when the COVID-19 diagnosis may not be the main one and, accordingly, mortality may be due to another disease (Biswas, 2020; RadioFreeEurope/RadioLiberty, 2020).

Thus, a severe disease course and COVID-19 related mortality are multi-factor processes that depend on the patient's age, concomitant pathology, and features of the death counting system.

\section{Results and Prospects}

COVID-19 quarantine measures have been adopted by almost all affected countries. India and Russia have started adopting the measures simultaneously. After this, there have been periods of gradual restriction lifting. It is worth noting that, due to stringency in restrictive measures in Russia and India, albeit in varying degrees, the measures displayed high effectiveness in combating the infection spread. It is important to note that to date, Russia has managed to achieve even more excellent results in limiting the spread of infection. So, on the date of 22 May 2020, a daily increase in the total number of COVID-19 cases by $2.8 \%$ was observed in Russia, while in India by 5\%. ${ }^{56}$ For comparison, the daily epidemic growth in Russia exceeded $16 \%$, and in India, it stood at $8 \%$ on the day of introduction of quarantine measures (Senapati et al., 2020; Teslova,2020).

Russia managed to achieve a greater reduction in the COVID-19 spread during quarantine compared to India. This phenomenon should be

\footnotetext{
${ }^{5}$ Please refer to footnote 3

${ }^{6}$ Coronavirus COVID-19 cases in India cross 1.1 lakh, death toll stands at 3435. Zee News. Retrieved on 22 May
}

studied more deeply. Quite interesting is the fact that in countries where there were strict restrictive measures, for example, in Italy, France, Spain, the death rate from COVID-19 per million population was about the same as in Sweden, where there were no strict restrictive measures.

Restrictive measures in different countries have become a substantial economic burden. Thus, experts cite similar data for India and Russia on the decline in GDP (about 5\%) caused by restrictive measures introduction (Choudhury, 2020; Sitdikov, 2020). Nevertheless, it should be assumed that milder restrictive measures may not be so destructive for the state's economic and social life and are most preferable provided that the fight against the spread of infection is highly effective. All this indicates the need for further epidemiological, economic and sociological studies, which will provide more accurate information on the impact of the restrictive measures on the economic, political and social life of various countries.

\section{Conclusion}

This study has discussed the quarantine measures adopted by India and Russia in their attempt to combat COVID-19. In doing so, the study draws the following conclusions:

Quarantine measures in India and Russia have shown a high degree of effectiveness. By 22 May 2020, the daily growth of COVID-19 in Russia decreased almost six times, in India - 1.7 times.

According to the results of 2020, the Gross Domestic Product (GDP) of India and Russia may decrease by equal $5 \%$ from the initial indicator, despite the difference in the restrictive measures severity degree.

\section{References}

Aleem, Z. (2020). India takes a small step toward relaxing its strict lockdown. Retrieved on 25 April 2020 from, https://www.vox.com/2020/4/25/21236183/in dia-coronavirus-lockdown-small-business

2020 from, https://zeenews.india.com/india/liveupdates/india-coronavirus-covid-19-live-updates-may-212285115 
Azad, A. (2020). CDC estimates that 35\% of coronavirus patients don't have symptoms. Retrieved on 31 May 2020 from, https://edition.cnn.com/2020/05/22/health/cd c-coronavirus-estimates-symptomsdeaths/index.html

Banerjea, A. (2020). Covid-19: Lockdown extended by two weeks with effect from 4 May, says MHA. Retrieved on 31 May 2020 from, https://www.livemint.com/news/india/covid19-lockdown-extended-by-two-weeks-witheffect-from-4-may-says-mha11588337761963.html

Basu, M. (2020). Is India's Covid-19 curve flattening? Cases now double every 10 days, from 3 before lockdown. Retrieved on 31 May 2020 from, https://theprint.in/india/is-indiascovid-19-curve-flattening-cases-now-doubleevery-10-days-from-3-beforelockdown/404616/

BBC News. (2020a). Coronavirus lockdown guidelines: What has India changed under new rules? Retrieved on 31 May 2020 from, https://www.bbc.com/news/world-asia-india52290761

BBC News. (2020b). India extends coronavirus lockdown by two weeks. Retrieved May 31, 2020, from https://www.bbc.com/news/worldasia-india-52698828

Biswas, S. (2020). India coronavirus: The "mystery" of low Covid-19 death rates. Retrieved on 28 April 2020from, https://www.bbc.com/news/world-asia-india52435463

Blavatnik School of Government, \& University of Oxford. (2020a). Variation in Government Responses to COVID-19" Version 5.0. Blavatnik School of Government Working Paper. Version 5.0. Retrieved on 31 April 2020 from www.bsg.ox.ac.uk/covidtracker

Blavatnik School of Government, \& University of Oxford. (2020b). Track government measures on COVID-19 with the Oxford Government Response Tracker. Retrieved on 31 May 2020 from,https://www.europeandataportal.eu/en/c ovid-19/stories/track-government-measurescovid-19-oxford-government-response-tracker

Bulut, C., \& Kato, Y. (2020). Epidemiology of COVID-19. Turkish Journal of Medical Sciences, 50(SI-1), pp. 563-570.

Business Standard. (2020). Coronavirus LIVE: Sikkim detects first case; Ahmedabad 24 deaths in a day. Retrieved on 31 May 2020, from, https://www.businessstandard.com/article/currentaffairs/coronavirus-live-updates-india-casesrise-global-covid-19-death-toll-corona-vaccineupdate-statewise-tally-latest-news120052300105_1.html

Centers for Disease Control and Prevention. (2020). Coronavirus Disease 2019 (COVID-19).11 February 2020. Retrieved on 31 May 2020 from, https://www.cdc.gov/media/dpk/diseases-andconditions/coronavirus/coronavirus-2020.html

Choudhury, S. R. (2020). Goldman Sachs gives India's growth forecast a 'gigantic downgrade.' Retrieved on 31 May 2020 from, https://www.cnbc.com/2020/05/22/coronaviru s-goldman-sachs-on-india-growth-gdpforecast.html

Chappell, B. (2020, 11 March). Coronavirus: COVID-19 Is Now Officially A Pandemic, WHO Says. NPR. Retrieved on 12 March 2020 from, https://www.npr.org/sections/goatsandsoda/2 020/03/11/814474930/coronavirus-covid-19-isnow-officially-a-pandemic-who-says

Decree of the President of the Russian Federation (dated 02.04.2020) N 239. (2020). On measures to ensure sanitary and epidemiological welfare of the population in the Russian Federation in connection with the spread of a new coronavirus infection (COVID19). Retrieved on 31 May 2020 from, http://www.consultant.ru/document/cons_doc _LAW_349217/

Decree of the President of the Russian Federation (dated 28.04.2020) N 294. (2020). On the extension of measures to ensure sanitary and epidemiological welfare of the population in the Russian Federation in connection with the spread of a new coronavirus infection (COVID- 
19). Retrieved on 31 May 2020 from, http://www.consultant.ru/document/cons_doc _LAW_351539/

Diwanji, S. (2020a). Daily cumulative of the coronavirus (COVID-19) confirmed, recovered and deceased numbers across India from January 2020 to May 2020. Retrieved on 22 May 2020 from, https://www.statista.com/statistics/1104054/in dia-coronavirus-covid-19-daily-confirmedrecovered-death-cases/

Diwanji, S. (2020b). Number of COVID-19 cases India 2020 by age group. Retrieved on 31 May 2020, from, https://www.statista.com/statistics/1110522/in dia-number-of-coronavirus-cases-by-age-group/

Dixit, M. (2020). TWC Explainer: How

Asymptomatic Individuals are Acting as Silent Spreaders of Coronavirus in India. Retrieved on 31 May 2020 from, https://weather.com/enIN/india/coronavirus/news/2020-05-13-howasymptomatic-individuals-acting-silentspreaders-coronavirus

Emami, A., Javanmardi, F., Pirbonyeh, N., \& Akbari, A. (2020). Prevalence of Underlying Diseases in Hospitalized Patients with COVID19: A Systematic Review and Meta-Analysis. Archives of Academic Emergency Medicine, 8(1), p. c35 insert DOI.

Hasell, J., Mathieu, E., Beltekian, D., Macdonald, B., Giattino, C., Ortiz-Ospina, E., Ritchie, H., et al. (2020). Coronavirus (COVID-19) Testing. Retrieved on 25 May 2020 from, https://ourworldindata.org/coronavirus-testing Henriques, M. (2020). In Italy, the death rate from Covid-19 is more than 10 times greater than in Germany. Why does the death rate vary so much internationally? Retrieved on 31 May 2020 from,

https://www.bbc.com/future/article/20200401 -coronavirus-why-death-and-mortality-ratesdiffer

India Today. (2020). Day 1 of coronavirus lockdown: India registers 101 new cases, 3 deaths; Govt says working to deliver essential services. Retrieved on 26 May 2020, from, https://www.indiatoday.in/india/story/day-1of-coronavirus-lockdown-india-registers-88new-cases-3-deaths-govt-says-working-todeliver-essential-services-1659742-2020-03-25

Jagannath, J. (2020). MHA allows movement of migrant workers, tourists, students stranded at various places. Retrieved on 29 April 2020 from, https://www.livemint.com/news/india/mhaallows-movement-of-migrants-touristsstudents-stranded-at-various-places11588164377351.html

Kang, Y.-J. (2020). Mortality Rate of Infection With COVID-19 in Korea From the Perspective of Underlying Disease. Disaster Medicine and Public Health Preparedness, pp. 1-3. Retrieved on 31 May 2020 from, https://www.ncbi.nlm.nih.gov/pmc/articles/PM C7156566/

Kluge, H. H. P. (2020). Statement-Older people are at highest risk from COVID-19, but all must act to prevent community spread. Retrieved on 31 May 2020 from,

http://www.euro.who.int/en/healthtopics/health-emergencies/coronavirus-covid19/statements/statement-older-people-are-athighest-risk-from-covid-19,-but-all-must-act-toprevent-community-spread

Lazzerini, M., \& Putoto, G. (2020). COVID-19 in Italy: Momentous decisions and many uncertainties. The Lancet. Global Health. Elsevier. Retrieved on 31 May 2020 from, https://www.ncbi.nlm.nih.gov/pmc/articles/PM C7104294/

Li, R., Pei, S., Chen, B., Song, Y., Zhang, T., Yang, W., \& Shaman, J. (2020). Substantial undocumented infection facilitates the rapid dissemination of novel coronavirus (SARSCoV2). Science. Retrieved on 31 May 2020 from, https://www.ncbi.nlm.nih.gov/pmc/articles/PM C7164387/

Mahase, E. (2020). Covid-19: Death rate is $0.66 \%$ and increases with age, study estimates. BMJ, 369, p. m1327. Retrieved on 31 May 2020 from, https://pubmed.ncbi.nlm.nih.gov/32238354/ 
Ministry of Health. (2020). Covid-19-Situazione in Italia. Retrieved on 31 May 2020, from, http://www.salute.gov.it/portale/nuovocorona virus/dettaglioContenutiNuovoCoronavirus.jsp? lingua=italiano\&id=5351\&area=nuovoCoronavir us\&menu=vuoto

Narayan, P., \& Nagarajan, R. (2020). Average age of India's Covid deaths 60; diabetes, BP common co-ailments. Retrieved on 31 May 2020 from,

https://timesofindia.indiatimes.com/india/aver age-age-of-indias-covid-deaths-60-diabetes-bpcommon-co-

ailments/articleshow/75037820.cms?utm_sour ce=contentofinterest\&utm_medium=text\&utm _campaign=cppst

Order of the Ministry of Education of the Russian Federation (dated 17.03.2020) No. 104. (2020). On the organization of educational activities in organizations implementing educational programs for primary, basic, general and secondary general education, educational programs of secondary vocational education, corresponding additional professional education and additional general educational programs, in the spread of a new coronavirus infection in the territory of the Russian Federation. Retrieved on 31 May 2020 from, http://www.consultant.ru/document/cons_doc _LAW_348249/

Order of the Ministry of Science and Higher Education of the Russian Federation (dated 14.03.2020) No. 397. (2020). On the organization of educational activities in organizations implementing educational programs of higher education and relevant additional professional programs, in the face of preventing the spread of new coronavirus infection in the Russian Federation. Retrieved on 31 May 2020 from, https://www.minobrnauki.gov.ru/ru/document s/card/?id_4=1064

RadioFreeEurope/RadioLiberty. (2020). Counting The Dead: How Do Counting Tolly The Toll from Covid-19. Retrieved on 31 May 2020 from, https://www.rferl.org/a/coronavirus- counting-the-dead-different-countries-russiausa-tajikistan-belgium/30624320.html

Ramesh, S., \& Basu, M. (2020). RO data shows India's coronavirus infection rate has slowed, gives lockdown a thumbs up. Retrieved on 31 May 2020from, https://theprint.in/science/r0data-shows-indias-coronavirus-infection-ratehas-slowed-gives-lockdown-a-thumbsup/399734/

Ritchie, H., Roser, M., Ortiz-Ospina, E., \& Hasell, J. (2020). India: Coronavirus Pandemic.

Retrieved on 25 May 2020 from, https://ourworldindata.org/coronavirus-india

Senapatia A., Rana1 S., Dasb T., Chattopadhyaya J. (2020). Impact of intervention on the spread of COVID-19 in India: A model based study. Cornell University. Retrieved on 30 April 2020 from, https://arxiv.org/abs/2004.04950

Sevillano, E., Linde, P., \& Vizoso, S. (2020). 640,000 rapid coronavirus tests arrive in Spain. Retrieved on 31 May 2020 from, https://english.elpais.com/society/2020-0323/640000-rapid-coronavirus-tests-arrive-inspain.html

Sitdikov, R. (2020). The economy during the pandemic: Russia's GDP decline in 2020 will be $5 \%$. Retrieved on 31 May 2020 from, https://1prime.ru/state_regulation/20200522/8 31492612.html

Soni, P. (2020). India's COVID-19 cases are now doubling every 12 days -That's a steady improvement. Retrieved on 31 May 2020 from https://www.businessinsider.in/india/news/indi as-covid-19-cases-are-now-doubling-every-12days-thats-a-steadyimprovement/articleshow/75534869.cms

SRD. (2020a). Distribution of new confirmed coronavirus (COVID-19) cases in Moscow, Russia from April 1 to May 26, 2020, by age group. Retrieved on 31 May 2020 from, https://www.statista.com/statistics/1109859/c ovid-19-cases-by-age-groupmoscow/\#statisticContainer

SRD. (2020b). Distribution of Coronavirus cases in Italy as of May 25, 2020, by age group. Retrieved on 31 May 2020 from, 
https://www.statista.com/statistics/1103023/c oronavirus-cases-distribution-by-age-groupitaly/

Statista Research Department (SRD). (2020). Cumulative COVID-19 cases in Russia as of May 22, 2020. Retrieved on 22 May 2020, from, https://www.statista.com/statistics/1107929/c umulative-coronavirus-cases-in-russia/

Teslova E. (2020, 03 March). COVID-19 infects more people in Russia, cases at 1,836. AA. Retrieved https://www.aa.com.tr/en/latest-oncoronavirus-outbreak/covid-19-infects-morepeople-in-russia-cases-at-1-836/1784927

The Economics Times. (2020a). Lockdown extended by 2 weeks, India split into red, green and orange zones. Retrieved on 31 May 2020, from, https://economictimes.indiatimes.com/news/p olitics-and-nation/govt-extends-lockdown-bytwo-weeks-permits-considerable-relaxations-ingreen-and-orangezones/articleshow/75491935.cms?from $=\mathrm{mdr}$

The Economics Times. (2020b). Kejriwal says COVID-19 deaths "very less", but 75\% cases asymptomatic or showing mild symptoms. Retrieved 31May 2020, from https://economictimes.indiatimes.com/news/p olitics-and-nation/75-percent-covid-19-casesin-delhi-are-asymptomatic-or-with-mildsymptoms-kejriwal/articleshow/75656666.cms The Hindu. (2020). Coronavirus / Central health teams to monitor 20 districts with heavy case load. Retrieved 31 May 2020, from https://www.thehindu.com/news/national/cor onavirus-record-jump-in-covid-19-deathscases/article31494977.ece

The Times of India. (2020). Covid-19 doubling time in India improved to 13.6 days in last 3 days: Harsh Vardhan. Retrieved on 31May 2020, from, https://timesofindia.indiatimes.com/india/covi d-19-doubling-time-in-india-improved-to-13-6days-in-last-3-days-harshvardhan/articleshow/75792169.cms?utm_sourc e=contentofinterest\&utm_medium=text\&utm_ campaign $=$ cppst
Tripathi, R. (2020). India's 21-day lockdown to counter coronavirus: What's exempt, what's not. Retrieved on 22 May 2020, from, https://m.economictimes.com/news/politicsand-nation/india-21-day-lockdown-what-isexempted-what-isnot/articleshow/74798725.cms

Verdict Foodservice. (2020). Covid-19: Several Indian states ban online food deliveries.

Retrieved on 27 May 2020 from, https://www.verdictfoodservice.com/news/cov id-19-indian-states-food-deliveries/

WHO. (2020). Coronavirus disease 2019 (COVID19) Situation Report-84. Retrieved on 14 April 2020 from, https://

www.who.int/docs/defaultsource/coronaviruse/situationreports/2020041 3-sitrep-84-covid-19.pdf?sfvrsn=44f511ab_2

Wisconsin Department of Health Services. (2020). COVID-19: Wisconsin Deaths. Retrieved on 31 May 2020, from https://www.dhs.wisconsin.gov/covid19/deaths.htm

World Health Organization (WHO). (2020). Coronavirus disease 2019 (COVID-19) Situation Report-31. 20 February 2020. Retrieved on 23 April 2020, from, https://www.who.int/emergencies/diseases/no vel-coronavirus-2019/situation-reports

Wu, Z., \& McGoogan, J. M. (2020).

Characteristics of and Important Lessons From the Coronavirus Disease 2019 (COVID-19) Outbreak in China: Summary of a Report of 72 314 Cases From the Chinese Center for Disease Control and Prevention. JAMA, 323(13), pp. 1239-1242. American Medical Association.

Zhou P., Yang X-L., Wang X-G. et al (2020). Discovery of a novel coronavirus associated with the recent pneumonia outbreak in humans and its potential bat origin. BioRxiv: The Preprint Server for Biology, doi: https://doi.org/10.1101/2020.01.22.91 